\title{
SOME OBSERVATIONS ON THE THECA OF DEVELOPING OVARIAN FOLLICLES
}

\author{
Margaret RYLE, Joyce KENT and Janice BOGGIS \\ with the technical assistance of Lesley WiLKins \\ United Birmingham Hospitals Department of Clinical Endocrinology \\ Birmingham and Midland Hospital for Women, Birmingham B $114 H L$ (U. K.)
}

\section{SUMMARY}

Three experiments were carried out to study factors affecting the development of the theca around small ovarian follicles. The ovaries were taken from infantile mice. $\mathbf{1}^{\circ}$ Ovaries were cultured in vitro for 4 and 8 days, with and without luteinizing hormone (LH). LH increased the percentage of follicles with $I$ and 2 layers of granulosa cells which were surrounded by complete thecal envelopes. $2^{\circ}$ Mice aged six days were injected with LH. Three days later alkaline phosphatase activity in their ovaries was more intense than in corresponding controls and extended to smaller follicles. $3^{\circ}$ Ovaries were cultured with and without lactic dehydrogenase in the medium. In the presence of the enzyme no thecal layer surrounded any follicles. They were separated by wide areas of «stromal " cells as though the thecal cells had de-differentiated. Possible interpretations of the results are discussed.

\section{INTRODUC'TION}

The theca interna of a Graafian follicle, but not of an early secondary follicle, shows ultrastructural features characteristic of steroidogenic tissue (CHRISTENSEN and GILLIM, I969). Luteinizing hormone (LH) labelled with ${ }^{125 i o d i n e ~ b i n d s ~ s e l e c t i v e l y ~}$ to thecal as well as to luteal cells in pregnant rats (RAJANIEMI and VANHA-PERTTULA, 1972). Similarly human chorionic gonadotrophin (HCG) labelled with 125iodine binds selectively to thecal and to interstitial cells in immature animals (PRESL, PospíšII, FIgAROVÁ and WAGNER, 1972). LH and HCG probably stimulate steroidogenesis in these cells, for the activities of various enzymes associated with steroidogenesis are enhanced in the theca interna, as in the corpus luteum and in the interstitial tissue by the two gonadotrophins (TAYLOR, I96I ; KUPPERS, 1967; KENT, in preparation). 
The primordial follicle has no thecal layer and, at least in immature mice, those follicles with growing oocytes (stages $3 a$ to 4 of PEDERSEN and PETERS, I968) often lack a complete thecal envelope. What factors control the growth and differentiation of this follicular component? BRANDAU (I970) commented that HCG initiated the formation of the theca in 7 day old mice. Conversely EsHroL, and her collaborators (ESHKOL, LUNENFELD and PETERS, I970 ; STEGNER, LUNENFELD and ESHKOL, I970) inhibited thecal development in infantile mice by injecting an antiserum raised against rat gonadotrophins. This inhibition was not countered by injections of follicle stimulating hormone (FSH), which suggests that $\mathrm{LH}$ was the necessary component for normal development.

Highly purified LH, like FSH, stimulates granulosa cell mitosis and therefore follicle growth in infantile mouse ovaries cultured in vitro. However this growth does not begin until the tissue had been exposed to the hormone for three days (RYLE, I97I a). This suggests that LH does not act directly on the granulosa cells. Follicles of sizes which typically have a complete thecal envelope grow rapidly in response to LH whereas smaller ones do not (RYLE, I972). If LH provoked thecal maturation and eventually initiated steroidogenesis, and if the stimulation of mitosis in granulosa cells was in some way associated with this steroidogenesis, then the delayed response to $\mathrm{LH}$ would be expected. Moreover it would occur principally in follicles possessing well developed thecal envelopes. These considerations led to the following in vivo and in vitro studies on infantile mouse ovaries. They confirmed that $\mathrm{LH}$ can stimulate thecal development and maturation. In addition they indicated that some other factor may also be important for normal morphological differentiation. The mice and the general culture technique were as described in RYLE (I97I $b$ ) and BoGGIS and RYLE (I972). Highly purified human pituitary LH was used throughout (HARTREE, BUTT and KIRKHAM, I963).

\section{EXPERIMENT I : MORPHOLOGICAL, DEVELOPMENT}

Infantile mouse ovaries were cultured for 4 and for 8 days either with no hormone or with I IU LH/ml of medium. There were 4 ovaries in each of the four subgroups. At the end of the culture period they were fixed and serially sectioned. The middle section of each ovary and the fifth and tenth sections on either side of it were examined. All follicles with growing oocytes and with either I or 2 layers of granulosa cells were recorded. The presence or absence of a complete thecal envelope around each was noted. The mean percentages of one-layered and two-layered follicles with complete thecae in ovaries cultured without hormone were compared with the mean percentages in ovaries cultured with LH. Text figure I shows that LH consistently - and in three of the four groups significantly - increased the proportion of small follicles with complete thecal envelopes. Thus the morphological development of the thecae was accelerated by LH. Moreover, of the 408 mitotic figures observed in the granulosa cells of these follicles, only two were in follicles lacking a complete thecal envelope, so granulosa cell mitosis was associated with greater thecal development. 


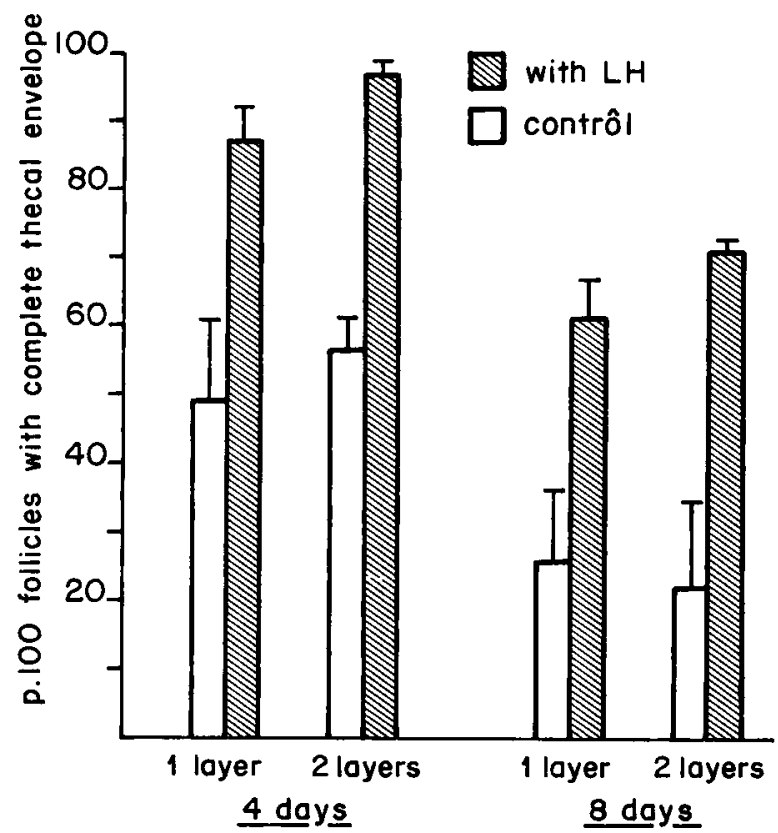

FIG. I. - Effect of $L H$ on development of theca in ovaries cultured for 4 and for 8 days. Percent of follicles with 1 layer and with 2 layers of granulosa cells showing complete thecal envelopes

FIG. I. - Effet de LH sur le développement des thèques dans des ovaires cultivés pendant 4 et 8 jours. Pourcentage de follicules à 1 et 2 couches de cellules de la granulosa montrant un développement complet des enveloppes thécales.

\section{EXPERIMENT 2 : HISTOCHEMICAL DEVELOPMENT}

The alkaline phosphatase activity of ovarian tissue appears to be highly sensitive to LH or HCG stimulation (J. KENT, T. A. BRAMLEY, in preparation). Intense activity is not seen in normal mouse ovaries until about 17 days after birth. The effect of $\mathrm{L}_{\mathrm{H}} \mathrm{H}$ on the activity of this enzyme in the thecae of growing follicles was examined as follows : Six day old mice were injected subcutaneously either with I IU of $\mathrm{LH}$ in $0.05 \mathrm{ml}$ buffer or with buffer alone. Three days later the mice were killed and cryostat sections of their ovaries were prepared without prior fixation. The sections were stained by the calcium cobalt method for alkaline phosphatase (PEARSE, I96I). Activity in the normal 9 day mouse ovary (fig. I) occurs as quite broad but diffuse bands around the larger follicles or as small intense patches associated with blood vessels. Little activity is present in the peripheral zone of the ovary where small follicles predominate. In contrast, the ovaries of mice injected three days previously with LH (fig. 2) show somewhat narrower but more intensely stained bands corresponding to the thecae of larger follicles. In addition narrow, active zones partly surround small peripheral follicles. Thus $\mathrm{LH}$ can promote histochemical differentiation of the thecae within a few days of birth and in very small ollicles. 


\section{EXPERIMENT 3 : THECAL, ORGANIZATION}

The previous experiments were concerned with the morphological growth and histochemical maturation of the theca. We have, in addition, some curious results - obtained in an experiment designed for a quite different purpose — which may be relevant to the induction and organization of the thecal layer from stromal cells. Ovaries from I5 day old mice were cultured for 3 days either with or without $I$ unit of lactic dehydrogenase per millilitre of medium (Sigma : rabbit muscle, Type I, lactic dehydrogenase). (Some culture dishes in each group also contained lithium lactate but this did not affect the results reported here). In the absence of lactic dehydrogenase thecal organization was normal with one or two well defined layers of flattened cells surrounding most growing follicles (fig. 3). In the presence of the enzyme, however, the cells adjacent to the granulosa were consistently disorientated and swollen (fig. 4). Adjacent follicles appeared to be separated by an excessive quantity of stroma. The thecal layer appeared to have dedifferentiated.

\section{DISCUSSION}

LOBEL and LEVY (I968) suggested that the formation of the theca was induced by the granulosa. Lactic dehydrogenase activity is normally quite marked in the granulosa cells of infantile mice (J. KENT, in preparation) and in small rat follicles (Pupkin, Bra'tT, Weisz, Lloyd and Balogh, I966). Perhaps the activity of this endogenous enzyme usually provides some material which induces transformation of adjacent stromal cells. The diffusion of lactic dehydrogenase from the medium throughout the cultured ovaries possibly masked this localized stimulation. Alternatively the enzyme may have inhibited the production of the essential organizing factor by the granulosa cells. L,H appears to stimulate mitosis of thecal cells since it promoted the extension and completion of thecal envelopes. It also stimulated their enzymatic maturation. At present we do not know if these actions of $\mathrm{LH}$ depend on the prior differentiation of thecal cells as a distinct flattened layer or not. Nor do we know what substance diffusing from the granulosa (if any) is the normal organizing agent.

\section{ACKNOWLEDGEMENTS}

We are indebted to Dr W. R. Burt for his constant encouragement, to the Ford Foundation for financial support and to Dr Anne Stockell HARTRe for our supply of luteinizing hormone. 


\section{RÉSUUMÉ}

\section{ÉTUDE DES THÈQUES DE FOLLICULES OVARIENS EN DÉVELOPPEMENT}

Trois expériences ont permis d'étudier quelques facteurs qui influencent le développement des thèques autour des petits follicules ovariens chez la Souris impubère.

Io Des ovaires sont cultivés in vitro pendant 4 et 8 jours avec ou sans LH. En présence de $\mathrm{LH}$ on voit augmenter le pourcentage de follicules avec I ou 2 couches de cellules de la granulosa qui sont entourés par des enveloppes thécales complètes.

$2^{\circ}$ Des Souris de 6 jours sont injectées avec LH. Trois jours plus tard l'activité phosphatase alcaline dans leurs ovaires est plus intense que chez les témoins de même âge, et elle apparaît dans des follicules plus petits.

$3^{\circ}$ Des ovaires sont cultivés dans un milieu contenant ou non de la lacticodéshydrogénase. En présence de l'enzyme, aucun follicule n'est entouré d'une couche thécale. De grandes plages de cellules «stromales » séparent les follicules comme si les cellules thécales s'étaient dédifférenciées.

\section{REFERENCES}

Boggis J., Ryle M., I972. An in vitro procedure for the quantitative measurement of follicle-stimulating hormone activity. J. Endocr., 54, 355-356.

BRANDAU H., 197o. Histochemical localization of enzyme activities in normal and gonadotrophin stimulated mouse ovaries. In Gonadotrophins and Ovarian Development. Edit. W. R. Butt, A. C. Crooke and M. Ryle. Edinburgh and London; E. and S. Livingstone, p. 307-311.

Christensen A. K., Gillim S. W., I 969 . The correlation of fine structure and function in steroidsecreting cells, with emphasis on those of the gonads. In The Gonads, Edit. K. W. McKerns, Amsterdam; North Holland Publ. Co. p. 4r5-488.

Eshiol A., Lunenfeld B., Peters H., 1970. Ovarian development in infant mice. Dependence on gonadotrophic hormones. In Gonadotrophins and Ovarian Development. Edit. W. R. Butt, A. C. Crooke and M. Ryle. Edinburgh and London; E. and S. Livingstone, p. 249-257.

Hartree A. S., Butt W. R., Kirkham K. E., I963. Biological and immunological properties of human pituitary follicle stimulating hormone obtained by starch gel electrophoresis. $J$. Endocr., 25, 54I-547.

KUPPERS S., I967. Zur Fermenthistochemie des Rattenovariums wahrend der postnatalen Entwicklung. Acta histochem. (Jena), 27, 267-284.

Lobel B. L., LeVy E., I968. Enzymic correlates of development, secretory function and regression of follicles and corpora lutea in the bovine ovary. Acta endocr., Copenh. 59, Suppl. I32.

Pearse A. G. E., I96r. Histochemistry (2nd. edition) p. 868, London; J. and A. Churchill.

Pedersen T., Peters H., 1968. Proposal for a classification of oocytes and follicles in the mouse ovary. J. Reprod. Fert, 17, 555-557.

Presl J., Pospíšil J., Figaroví V., Wagner V., r972. Developmental changes in uptake of radio activity by the ovaries, pituitary and uterus after ${ }^{126}$ I-labelled human chorionic gonadotrophin administration in rats. $J$. Endocr., 52, 585-586.

Pupkin M., Bratt H., Weisz J., Lloyd C., Balogh K., rg66. Dehydrogenases in the rat ovary. I. A histochemical study of $\Delta^{5}-3 \beta$ and $20 \alpha$-hydroxysteroid dehydrogenases and enzymes of carbohydrate oxidation during the estrous cycle. Endocrinology, 79, 316-327.

Rajaniemi H., Vanha-Pertiula T., 1972. Specific receptor for LH in the ovary : evidence by autoradiography and tissue fractionation. Endocrinology, 90, I-9.

RyLE M., I97I $a$. The time factor in responses to pituitary gonadotrophins by mouse ovaries in vitro. J. Reprod. Fert., 25, 61-74.

RYLE M., I97I $b$. The activity of human follicle-stimulating hormone preparations as measured by a response in vitro. J. Endocr., 51, 97-107.

RYLE M., I972. The growth in vitro of mouse ovarian follicles of different sizes in response to purified gonadotrophins. J. Reprod. Fert., 30, 395-405.

STEGNer H. E., LUNENFELd B., Eshkol A., I970. Ultrastructural ovarian changes after deprivation of endogenous gonadotrophins and the effect of FSH and HMG in the deprived immature animals. 
In Gonadotrophins and Ovarian Development. Edit. W. R. Butt, A. C. Crooke and M. Ryle. Edinbúrgh and London; E. and S. Livingstone.

TAYLOR F. B., I96I. Histochemical changes in the ovaries of normal and experimentally treated rats. Acta endocr., Copenh., 36, 36r-374.

\section{PLATE I}

FIG. I

Alkaline phosphatase activity in ovary of normal 9 day old mouse.

\section{FIG. 2}

Alkaline phosphatase activity in ovary of 9 day old mouse injected three days previously with I IU of LH.

\section{FIG. 3}

Follicles in ovary cultured with no lactic dehydrogenase in the medium.

$$
\text { FIG. } 4
$$

Follicles in ovary cultured in the presence of lactic dehydrogenase.

\section{PLANCHE I}

\section{FIG. I}

Activité phosphatase alcaline dans l'ovaire d'une Souris de 9 jours (témoin).

FIG. 2

Activité phosphatase alcaline dans l'ovaire d'une Souris de 9 jours ayant reçu trois jours plus tôt I UI de LH.

\section{FIG. 3}

Follicules dans un ovaire cultivé dans un milieu sans lacticodéshydrogénase.

FIG. 4

Follicules dans un ovaire cultivé en présence de lacticodéshydrogénase. 

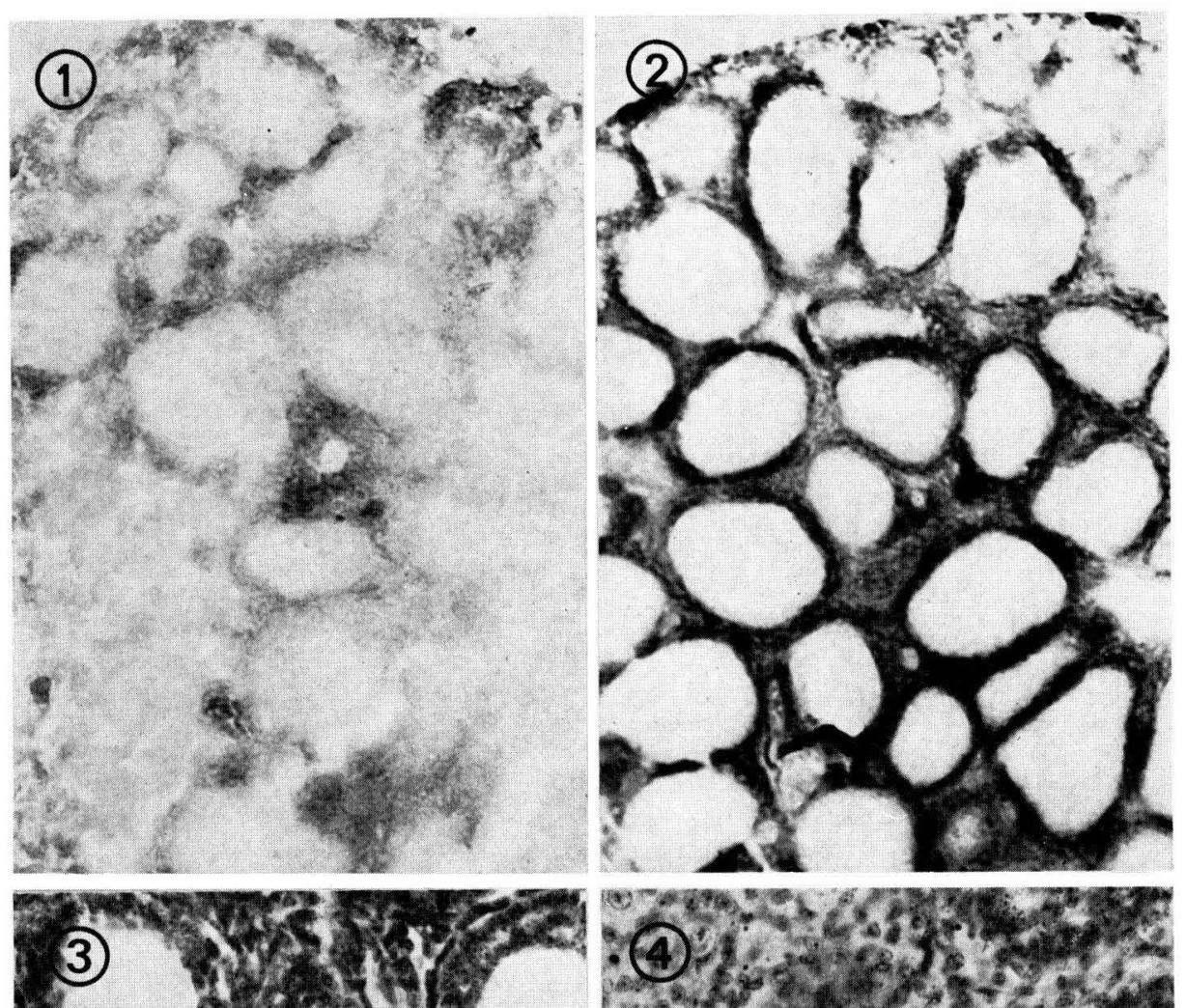

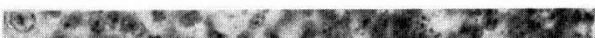

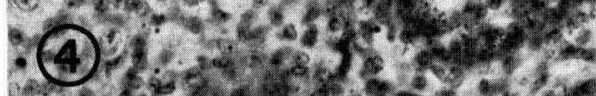

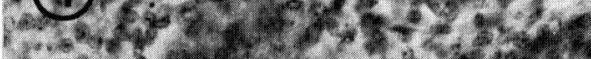

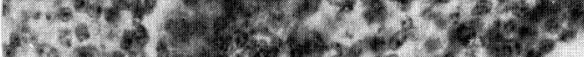

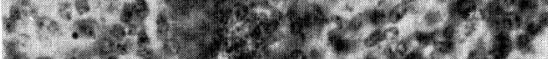

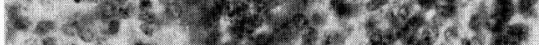

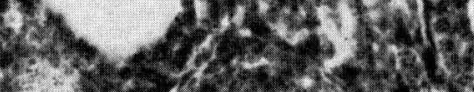

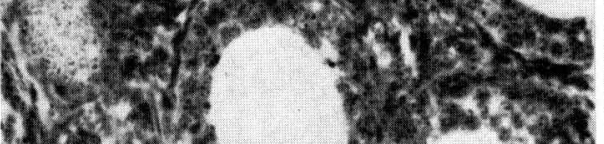

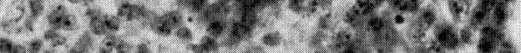

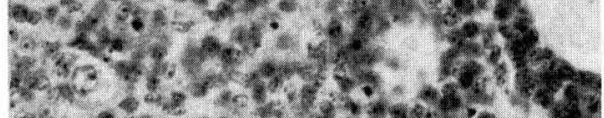

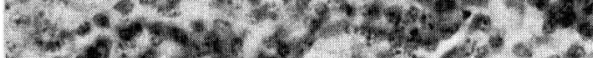

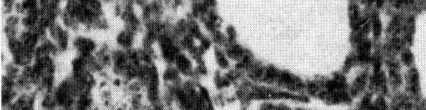

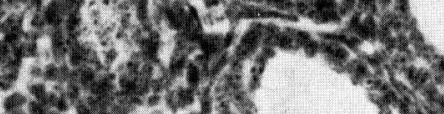

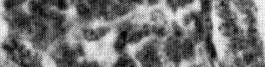

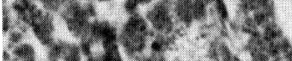
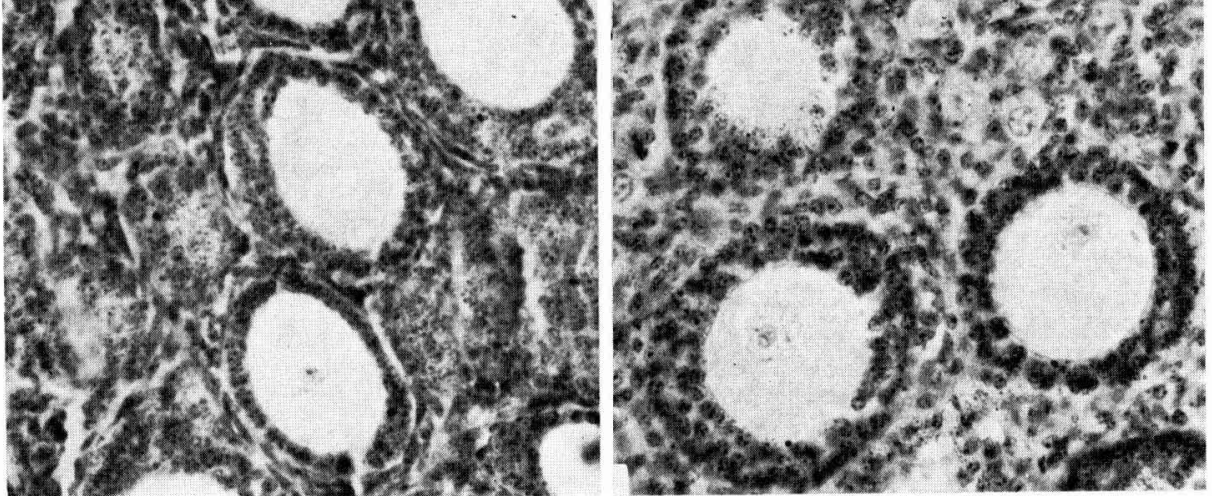

M. RYLE, J. KENT and J. BOGGIS 